\begin{tabular}{ccc}
\hline \hline 技 術 資 & 料 \\
\hline \hline
\end{tabular}

\title{
鋼のオーステナイト結晶粒度の現出法について
}

\author{
今井勇之進*,広谷宏**
}

\section{ON THE METHOD FOR REVEALING THE AUSTENITIC GRAIN SIZE IN STEEL - A REVIEW-}

Yûnoshin Imai, Dr. Eng., \& Hiroshi Hirotani

\section{I. 緒}

$\overline{\overline{\bar{~}}}$

鎆の性質はオーステナィト結晶粒度によつて火总く左 右されるのでー4，使用目的に応じて滴当なオーステナ イト結晶粒度を有する鋼材を選げなけれ淰ならないがそ のオーステナイト結晶粕度を正確，迅速加つ簡笨に非定 できる方法が先ず必要になつてくる.1922年 McQuaid, Ehn が渗炭法によりオーステナイト絬晶粒の現出方䄈

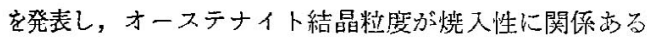
ことを指摘して以来才ーステナイト結晶精度の現出方洼 加数多く発表され出し，さらにそれら現出法の適用性に 関して子種々比颙検討されてきている，著者らるこれら 現出法を概観し，ての㧍の打のの長短所についてもあえ て論及した。

\section{II. 現出方法の種類ならびに分類}

\section{1. 渗炭法子墨鉛堆積法}

渗炭性ガスと鋼材表面との反応抢よび炭素の鋼材内人 の熔解拡散現象によつてこの現出方法は成立するので念 るが，今日この方法は一般に䇣炭法と呼ばれているもの と黒鉛堆積法といわれているものと2 㮔類がある.

\section{i ) 俢炭法}

1922 年に McQuaid, Ehn12は適当な大きさの試片 を所定の渗炭剂とともに函中に密閉し，それを空気中で 所定温度, 時間オーステナイト化してから徐冷し，この 試片の切断面を研磨仕上け゚しピクリン酸ソーダ溶液で煮 沸，むしくは硝酸またはピクリン酸アルコール溶液で腐 鳋し，過共析セメンタイトの網状組繊を現出して渗炭鋼 の異常組織を研究して以来今日まで広く採用されてい る. 渗炭抄としてょく使用される炭酸バりウムの量を変 活粒度は変化しないことも明らかにされているう。 写真 1 は渗炭法による代表例である.

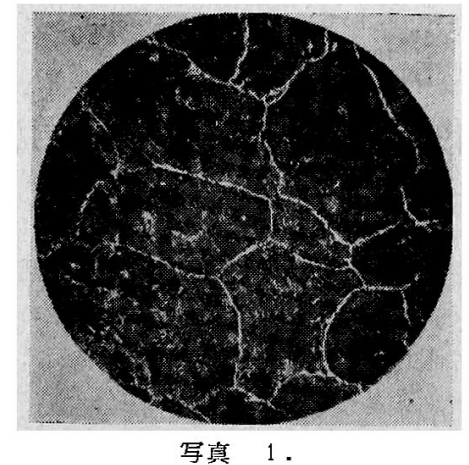

方法; 炭法

试料; 過共析鋼

条件； $925^{\circ} \mathrm{C}$, 8h 才ーステナイト化 $5 \%$ ピクリン酸零蝕

(McQuaid-Ehn)

ii）黑剩堆槕洼;

1952 年, 河上, 藤は ${ }^{6}$ 試料面の一部を娭鏡讪 来万程 度に仕上げた後, 木炭粉中に埋めて $925^{\circ} \mathrm{C}, 2 \mathrm{~h}$ 保持後 試料面全く噟蝕せず検鏡し絬晶粒界に沿うて黑鉛が堆 積するところからその鋼材のオーステナイト結晶粒度を

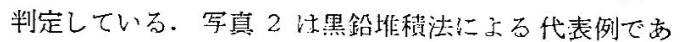
る.

2. 熟処理法

熱処理法の中には徐冷法, 㜔入法, 二回䡒入法, 停止 焼入法, 一端焼入法なぞ多くの種類があるが, 結晶粒界 の現出の機構は適当な熱処理によつてオーステナイト結 晶粒界に沿つてセメンタイト,フェライト,パーライト むしくはトルースタイトのいずれか在析出させ腐炡によ つてマトリックスとそれら析出物とを区别して元のオー

* 東北大学工学部教授

** 東北大学金属材料研究所 


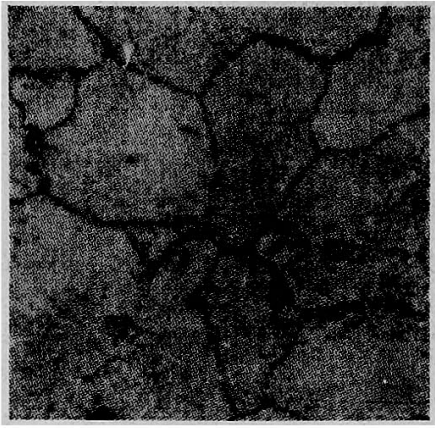

写真 2 .

方法；黑鉛堆䅣法

試料; 電解鉄

条件； $925^{\circ} \mathrm{C}, 2 \mathrm{~h}$ オーステナイト化 窝蝕せず

（河上，藤）

ステナイト結晶粒度を測定するか，あるいは方向性のあ るマルテンサイト組織の現出によつてオーステナイト結 晶境界を知るかのいずれかである．村上》は1942 年ま での各種オーステナイト結晶粒度現出法を総括している がその中で熱処理法を採用して結晶粒度を求めるにはつ ぎのような操作を行うと良い結果が得られることを明ら かにされた。すなるち

(1) 徐冷汒

過共析鋼または亜共析鎆 $(0.45 \% \mathrm{C}$ 以上) を炉中玲却 または空中放冷するときは初析セメンタイトまたは初析 フェライトが各オーステナイト結晶粒の境界に析出す る.このパーライトの地家围えだ網状のセメンタイトを たはフェライトはオーステナイトの結晶䊀を示寸。ゆえ に試料字 $\mathrm{A}_{3}$ または $\mathrm{Acm}$ 点以上より泠却しその断面 を研磨し硝酸またはピクリン酸で検鏡すればよい。

(2) 烧入法

(i) 停止烧入法8》

試片を変態点以上の高温度に熱した後，その鋼の変態 範囲内のある温度に熱してある熔融 $\mathrm{Pb}$ ，または塩浴中に 入え，数秒ないし数十秒間保持後水冷する、このように すると短時間の冷却中止中に䏶共析フェライトがオース テナイト結晶粒界に析出し，つきの焼入れによつてオー ステナイトの残部がマルテンサイトに変化する．この試 料を研磨後酸で鹰蝕するとマルテンサイトの部分を囲て で網状のフェライトまたはトルースタイトが現泏されこ れによつて元のオーステナイト結晶粒度を測定すること ができる．この方法によつて最良の結果を得るような停 止時間と温度は試片の大きさ，組成などによつてことな る.この方法は徐泠法に適用される鋼より
をのに用いられる。.

(ii) 一端烍入法9

㨁径約 $15 \mathrm{~mm}$ 長さ約 $40 \mathrm{~mm}$ の試片をとり，乙れを 高温㢑 (学振法では $925^{\circ} \mathrm{C} ， 2 \mathrm{~h}$ ) に熱した後その一端 的 $10 \mathrm{~mm}$ を水中に垂直に浸して急冷する.つぎこの 試片を表面約 $5 \mathrm{~mm}$ の深さむで維方向に削除し, 研磨 してから酸で腐蝕，検鏡する．この場合水中に急冷した 先端の部分は腐蝕され難いマルテンサイト，他端の空中 放玲された部分はフェライトまたはせメンタイト（過共 析銅）とトルースタイト（またはパーライト）より成り 水中に急冷した一端から空中放冷された他端までの間に はマルテンサイト組織の周囲にトルースタイトの網状に 連なる部分があり，さらに示そく冷却された部分には低 炭装銅 (0.45\%C 以下) ではトルースタイトの地にフェ ライトが網状に㙛なり，また過共析鋼（1・2\%C 以上） ではセメンタイト唯網状に析出する部分があるのでこれ らの個所でオーステナイト結晶粒度を知ることが出来 る. “Jominy Test” は同時にこの試験も行い得る.

(3) マルテンサイト腐蝕法

䡒入試料が全部マルテンサイトになつているような場 合に適用されるぬのであり，噟蝕郕としてはアルコール $950 \mathrm{cc}$, 濃塩酸 $50 \mathrm{cc}$, ピクリン酸 $0.7 \mathrm{~g}$ の試薬が胶果的 である.オーステナイト結晶粒が現われ難い場合は適当 に焼庆すとよい場合がある。

（4）二回焼入法

直径に比して数倍の長さをるつ試料を所定温度に達し た後水中に焼入れ，つぎにその一端をその銅の $\mathrm{A}_{1}$ 変態 点より $40 \sim 70^{\circ} \mathrm{C}$ 高い温度の塭浴，または金属 $\mathrm{Pb}$ 中に約 $30 \mathrm{mn}$ 浸してから試料全部を水中に焼入れ，その後表面 を削除して研磨腐蝕しマルテンサイトの網状に現牥した 部分を検鏡する.鋼を高温度より焼入れ一様なマルテン サイト組織とした後, 徐々に加熱する時はマルテンサイ トはトルースタイトとなりついでソルバイトとなり。 $\mathrm{A}_{1}$ 変態点に達するとき湴元のオーステオイト粒界より 漸次オーステナイトに変化する.したがつて $\mathrm{A}_{1}$ 変態点 よりや〉高い温度に達した時水中に焼入机る之上述の変 化したオーステナイトはマルテンサイトとなるのでこれ を研磨し腐蝕するには元のオーステテナイト結晶粒界に網 状のマルテンサイトが現われる。

Davenport, Bain 10 は熱処理法によつて良认結果 得るには鋼中に含有されていい元素量によつて熱処理 変える必要があるこしなどを明ら办にしているか，ての 他後述のように熱処理法と他の方法とを比較誡験した研 究もある. 


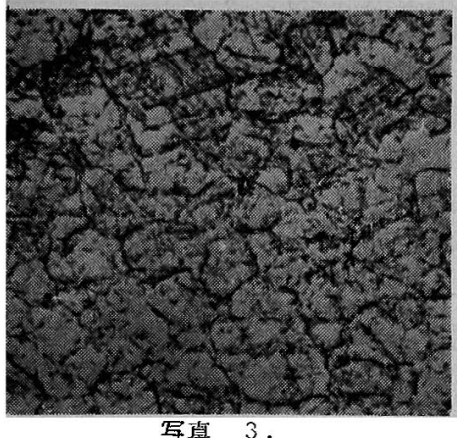

写真 3 。

方法：マルテンサ1ト窝蝕法

武料; 炭萃鎆

条件；ピクリン酸㙁酸アルコール溶滩 窝蝕

(Vilella, Bain)

焼入法の一例として等真了索揭げた。

\section{3. 酸化法}

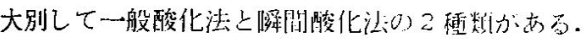

\section{i) 一般酸化法}

結晶粒界の方が粒内よりも物理的, 化学的に“Active” であることを利㸝したものである.1936 年に He-

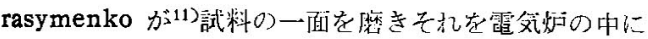
入れ空気中にさらしたまつでオーステナイト化温度まで 加熱し 所定時間経過後水冷もしくは油冷してから酸化 層を適当に取除き $2 \%$ 硝酸アルコール溶液で應触してオ ーステナイト結晶粒度を判定している。その一例炎军真 4 に示打. その後 1942 年に米国の“Steel Standardization Group” は12)オーステナイト結晶粒の現出洼 として俢宸法の外に酸化法范毛推奖し，その現出方法を らぎのように規格化している.すなおち試料衣面を 400

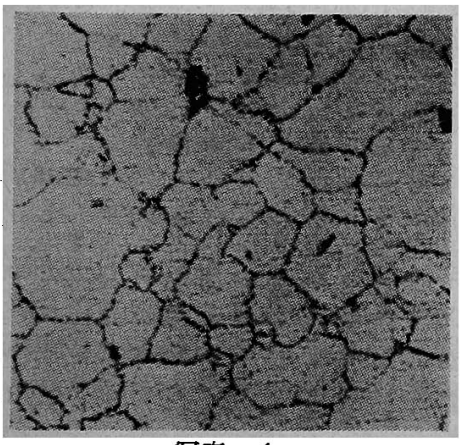

写真 4 .

方法; Herasymenko 酸化法

武料; $0.4 \% \mathrm{C}, 1 \% \mathrm{Ni}, 0.6 \% \mathrm{Cr}$ 鎡

条件; $824^{\circ} \mathrm{C}$ オーステナイト伦， $2 \%$ ナイタル窝蝕

(Herasy menko)
番アランダムを用いて㸴磨し，沴炭を行わない䤱材の場 全は侏磨面を上问きにし， $871^{\circ} \mathrm{C} に 1 \mathrm{~h}$ 加熱後水中また

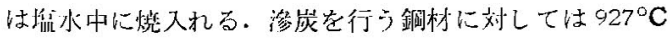
に $6 \mathrm{~h}$ 加熱後水けまたは䘏水中に焼入れる。最初の $5 \mathrm{~h}$ は珷片に覆い老被せて過度の酸化を抑製し最後の1 h だ け完全に大気中にさらす. 腐蝕液としては 15\% 炡酸エ チルアルコール溶液を用い大体 2〜 $5 \mathrm{mn}$ 曜玲卞る. た 1938 年に Tobin, Kenyon ${ }^{13)}$ 《試料0)邀剩な酸化 を防くために試料定木炭粉，酸化鉄 $\left(\mathrm{Fe}_{3} \mathrm{O}_{4}\right)$ 抢よび鉄 のや寺りくずの混公されたもの〉中，もしく海浴榑の 中に試料を入れてオーステナイト化し，オーステナイト 化処理の最後の数秒間だけ自然酸化をしてから急冷しそ の試料表面維晶粒界が消失しない程度に再研魔してか ら $15 \%$ 塩酸アルコール溶液で腐強して 鮮明に結晶粒界を現出させている。なお Herasymenko は前述の酸化法の試駼を行つた際過剩な酸化党防ぐため 高真空中で試料をオーステナイト化した後約 $15 \mathrm{mn}$ 自然 酸化してから水冷する方法も行っている.

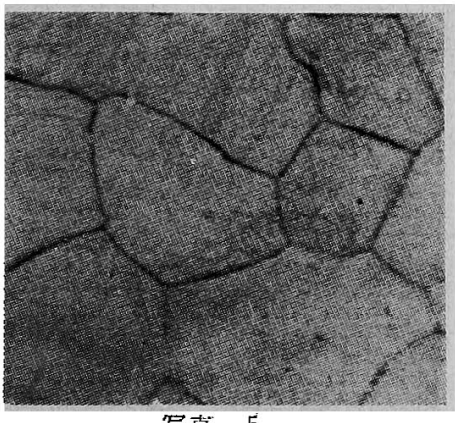

方法; 弱酸化法

坛料; $U \cdot 8 \% \mathrm{C}$ 鎙

条件; 限られた空気量の密閉容器中で $1093^{\circ} \mathrm{C}$, 9h オーステナイト化 ᄂ $10 \%$ 隻海水中に烧入, $15 \%$ HCl アルコール溶液触

(Tobin, Kenyon)

ii) 瞬間酸化法

1955 年に遠藤,大竹が 14 $^{14} 10^{-4} \mathrm{mmHg}$ の真空中で鏡面 に仕上げた試料をオーステナイト化し，所定時問保持後

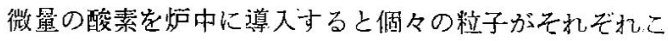
となつた方向性を持つているところから，それら結晶 粒がことなつた色を呈することに着眼してオーステナイ 卜結晶粒度を判定した。察真 6 にその一例を示す。 た 1958 年に箸者らは15瞬間酸化の簡便法として鏡面仕 上げした試料を $10^{-4} \mathrm{mmHg}$ の真空中でオーステナイ 卜化し所定時間絴過後灯を開いて試料を取り出す时に試 


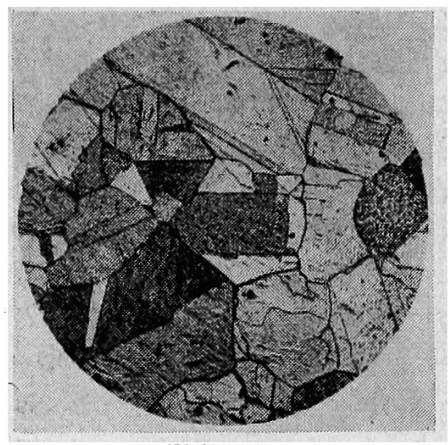

写真 6

方法；高温酸化着色法

試料; 七ミキルト銅

条作： $1100^{\circ} \mathrm{C}, 20 \mathrm{mn}$ オーステナイト

化，窝触せず（遠藤，大竹）

料表面艺自然酸化させた汒台几溶融状態の嗍砂(約 900 $\left.{ }^{\circ} \mathrm{C}\right)$ (浸すと試料の表面に生成された酸化物は硼砂に 溶け酸化の進行の早い結晶粒界はこのために溝状に現わ れることを利用してオーステナイト結晶粒度を判定して いる. 写真7はての一例である。

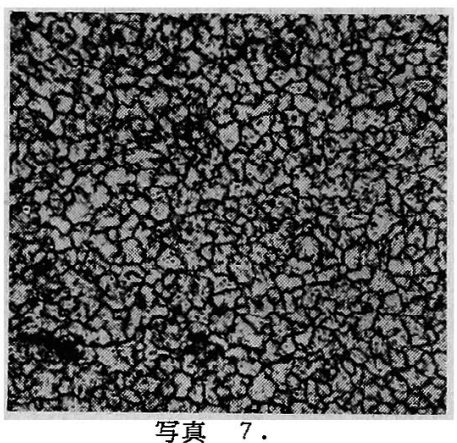

方法; 瞬間酸化簡便法

試料； $10 \% \mathrm{Cr}-\mathrm{Fe}$

条件； $1000^{\circ} \mathrm{C}, 3 \mathrm{~h}$ オーステナイト化 し, 溶融砋砂 $\left(900^{\circ} \mathrm{C}\right)$ 《 $30 \mathrm{sec}$ 浸清，筒蝕せず

(今井，広谷）

4. 侵蝕性ガスによる方法

高温において侵蝕性ガスを鋼に作用させれば腐蝕速度 の差異により結晶粒界のみならず，その温度での素地の 組織定无現出可能なところから Osmond, Cartand ${ }^{16)}$, その他 ${ }^{17) 18) は ~} \mathrm{Cl}$ また $\mathrm{HCl}$ ガスを用いて高洫における 組織の研究をしたるのがあるがオーステナイト結晶粒度 の判定用としては 1937 年に O'Neil が Cl ガス空使用 して高温腐蝕行いその結果を他の方法によるものと比 較梌討している. 近年には. $\mathrm{H}_{2}$ 中または $\mathrm{N}_{2}$ などのガス
中で鏡面仕上げした多くの鋼種をオーステナイト化しそ の温度で $\mathrm{HCl}$ ガスを用いて腐蝕を行い，ガス腐蝕法が 庆籁囲に利用できること党明らかにした河上，染野の研 染19)，および江口年のガス腐䖵面定金属顕微鏡ならびに 電子顕微鏡で観察した研究がある. 写真 8 おびのはガ ス鹰䘀によつてオーステナイト結晶粒を現出させた一 例である。

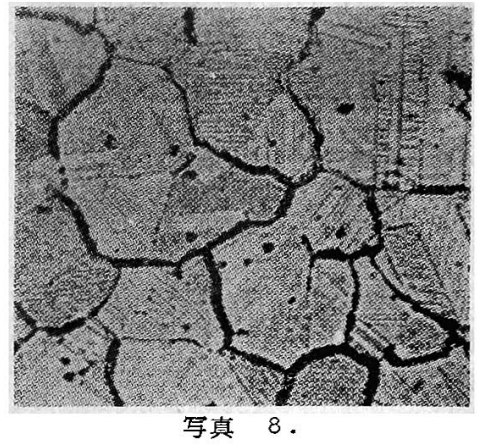

方法; ガス窝蝕法

試料；18-8 ステンレス銿

条件； $1000^{\circ} \mathrm{C}$ でオーステナイト化， $\mathrm{HCl}$ ガスで腐蝕

(河上, 染野)

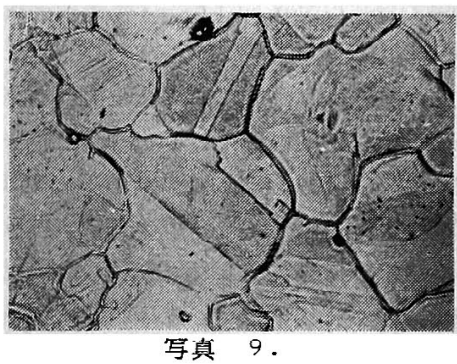

方法；ガス窝触法

試料; 低炭素銅

条件； $935^{\circ} \mathrm{C}, 30 \mathrm{mn}$ オーステナイト 化, $\mathrm{HCl}$ ガス笍鳋

(江口)

5. 没体溶融境觉用いる方法

1897 年および 1898 年に Saniter は21)鏡面研磨した 試料を $800^{\circ} \mathrm{C} \sim 900^{\circ} \mathrm{C}$ の熔融状態の塭化カルシウムに 浸漬してから水冷しオーステナイト結晶粒界やマルテン サイトの針状組織現化した，京た 1900 年, Osmond は22)严共析鋼および滲炭銅を $960^{\circ} \mathrm{C}$ の塩化カルシウム 中で加熱し高温組織を研究している.

6. 熱歷触法

1888 年に Osmond が23)水素気流中で鏡面仕上げし た試料壱オーステナイト化し，試料表面は脱炭していた 
か゚その試料表面にオーステナイトの絧状組織を現出させ

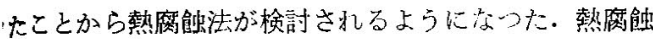
法によつてオーステナイト結晶粒界が現われる瑟由上し $\tau$ Rosenhain, Ewen ${ }^{24}$ は真空中でオーステナイト化し た試料が重量減少安来しその減少率恃微細結晶粒のもの 〉方が粗粒の場合よりも大きいことから結晶粒と結晶粒 との間には“Amorphous Cement”があつて真空加 㷫によつてそれが失犼ると仮定し，さらに Kaye， Ewen ${ }^{25}$ 子電解鉄真空中で加熱した实駼方ら前述の “Amorphous Cement” の蒸発によつて精界が满状に 現われるとの仮定を立てているが表面張力説なども49)あ る. 熱腐蝕法による鋼の高温組織の斫究はOsmondに 続いて Oberhoffer ${ }^{18)}$, O'Neil126) 達が行つている。さ らに1940年には Day, Austin ${ }^{27}$ 多，1942 年には Mill-

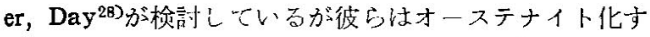
る際の不活性ガスの純度特に $\mathrm{O}_{2}$ 星によつて現出される 粒度に差が生じ吕埸合があるので O。量をできるだけ 少なくする必要があること，およびオーステナイト化処 理後同一雾国気中で徐冷与る上成長前の結晶粒界, フェ ライトの結晶粒界などが現出されて，真の結晶粒度を判 定するのに困難安招くのでオーステナイト化処理後大文 にさらすことなしに $\mathrm{Hg}$ 中に焼入れると試料表面にしわ ができ，それが前記の不必要な粒界を消失させ鮮明に刻 まれた真の粒度の判定が出来ることなどを明らかにして いる.焼入用の媒体として Hg 学用いるのは急冷もでき， 酸化も脱㟶むさせず，研磨面索荒すこともない加らであ る.なお，オーステナイト化の際の不活性ガスに $\mathrm{H}_{2}$ を 使用しても試料の脱炭はごくわずかであること， $\mathrm{H}_{2}$ と 窒素の混合気体，および窝素だけを使用しても試駼可能 であることを稚認している. 1952 年までの熱應蝕に関 する交献を Olney ${ }^{29}$ はとりまとめて発表しているがそ の後 1956 年に Færden ${ }^{30}$ ’が高 $\mathrm{Cr}$ 鈰に対して熱腐 蝕法を適用している，写真 $10 １ 1$ は熱腐蝕法による一 例である．最近は熱應蝕応用する優秀な国産の高温顕 微鏡が出来, これによるオーステナイト結晶粒の研究も されている54)55).

7. 破断法（破面検査法）

オーステナイト化温度加ら水中もしくは塩水中に焼入 れしてマルテンサイト変態を生じ, いわ哃鋼材が脆化 した場合その試料定破断しその破唽面に光を当てると光 は破断面の状態によりてそれぞれことなつた乱反射をし 肉眼でその乱反射の度合いから粒の大きさ老推定するの が可能であるところから 1926 年頃より破断法が適用さ れるようになつた。

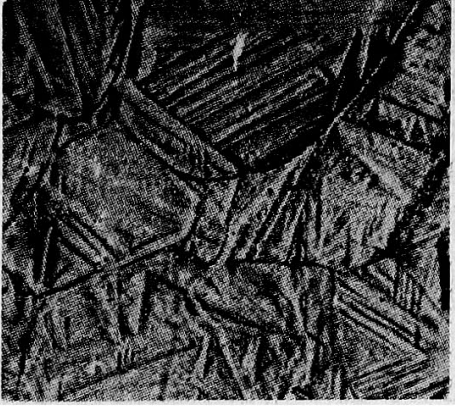

写真 10 .

方法；熱窝蝕法

試料; $0.4 \% \mathrm{C}$ 䒁

条件； $1000^{\circ} \mathrm{C} ， 2 \mathrm{~h}$ オーステナイト化 し真空中烧入，腐能甘ず

(Olney)

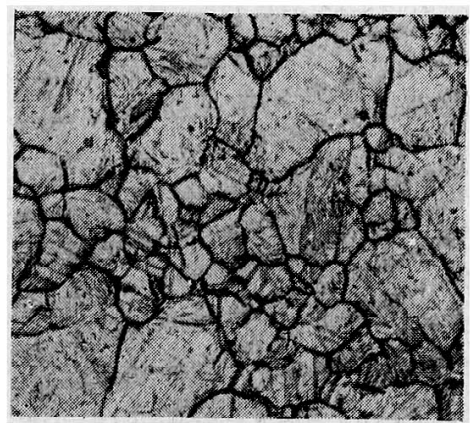

写真 11 .

方法；熱管蝕法

武料; $11 \% \mathrm{Cr}$ 釾

条件; $1070^{\circ} \mathrm{C}, 10 \mathrm{~h}$ オーステナィト化 し, 炉空除いて真空中で空冷, 窝蝕せず

(Færden)

1926 年まずスエーデンの“Uddeholm Steel Works” でこの方法をとりあげその後 Jernkontoret の指揮の 下に “Swedish Iron Master's Association" て 検討し，1927 年には破面检查に必要な10段階の “Standard Scale”扩よびその標本も Ragnar Arpi の指導の下に作成された。米国においては Shephard ${ }^{31}$ がその適用性を検討しており，Jernkontoret's Shephard's chart はともに A.S.T.M. できぬオーステナ イト結昆粒臂番品上関速性のあることを Vilella 達は認 め,さらにマルテンサイト化した試料の破断が元のオー ステナイト縄昆粒界に沼うて起ることも明らかにしてい る. 近年, Færden ${ }^{30)}$ は高 $\mathrm{Cr}$ 鋼を最初熱腐蝕を行つ てから液体 $\mathrm{O}_{2}$ 中に投入して破断を行い写真 12 のよう 


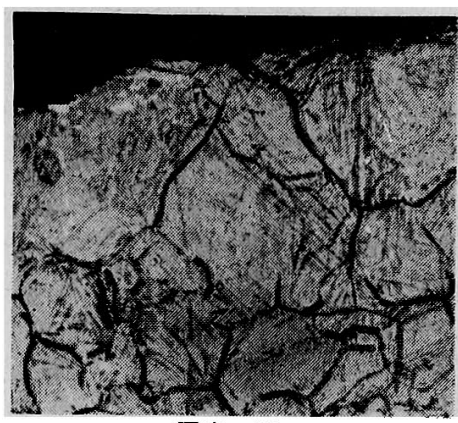

写真 12 .

万法; 破断法

試料; $11 \% \mathrm{Cr}$ 舒闭

条件： $1045^{\circ} \mathrm{C}, 10 \mathrm{~h}$ オーステナイト

化儿，液休酸琹中心佊断

(Færden)

(破断はオーステナイト絃界に沿つて起万)

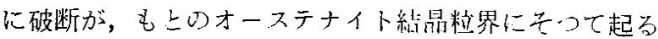
ことを諗めている。

8. 金翼拡散法

i) $\mathrm{Cu}$ 掘散法

鋼に対してCuが“Intergranular Diffusion” する 性質を利羽してオーステナイト結晶粒界希出させる方 法で 1949 年に Eckel, Paprocki は22オオーステナイト 化と拡散と老同時に行うと所定温度，時間でオーステナ イト化する前に拡散したCuのために真のオーステナイ 卜結晶粒度を現出できない場合があるこころからオース テナイト化と拡散の操作を分彗して実駼を行つている. 本現出法の大䒺はつぎのようなものである.オーステナ イト化の時，試料が酸化せ始よう2 個の試片の片面ら〉

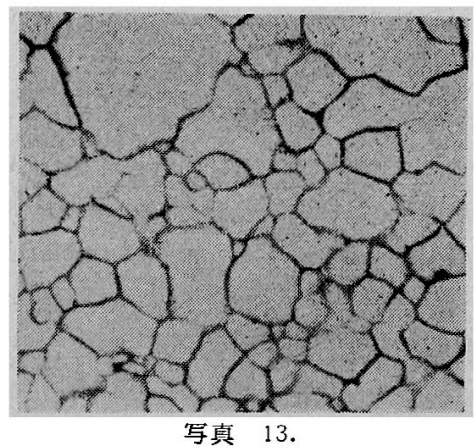

方法; 銅捄散法

試料； $0.4 \% \mathrm{C}$ 鋼

条件； $899^{\circ} \mathrm{C}$ でオーステナイト化，溶 融 $15 \% \mathrm{P}-\mathrm{Cu}$ 中に $30 \mathrm{mn}$ 浸 涉 $\rightarrow$ 水焼入

$4 \%$ ピクリン酸窗蝕

(Eckel, Paprocki)

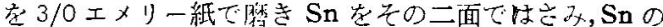

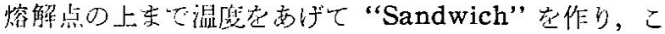
犯机炭㸮中でオーステナイト化する。所定㭙開経過後 $85 \% \mathrm{Cu}+15 \% \mathrm{P}$ 江適当大“Flux”灰入机た浴媒状態

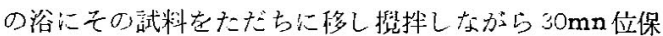

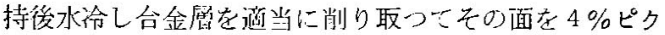

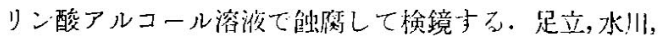

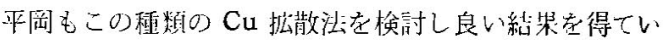

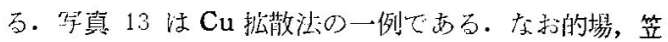
松33はこの方法に抢いてオーステナイト化の際の試料の

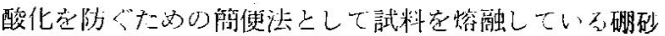
の中に入秃て加熱した㷋, 約 $30 \mathrm{mn} た ゙ け \mathrm{Cu}-\mathrm{P}$ 合金溶 に浸けて満足な絬果を得ている。

ii) $\mathrm{Pb}$ 拡散法

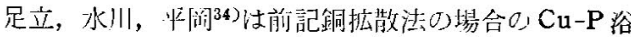
のかわりに $\mathrm{Pb}$ 浴を优用して $\mathrm{Pb}$ 定鉄銅中心 “Intergranular Diffusion”させせ粒度判宝に成功している。

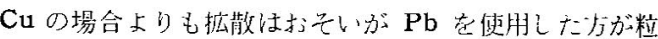

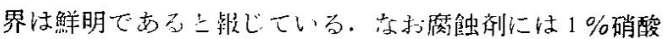
アルコール溶液が效果的であるこを等も明らオにてい る。写真 14 は $\mathrm{Pb}$ 拡坆法による代表例である。

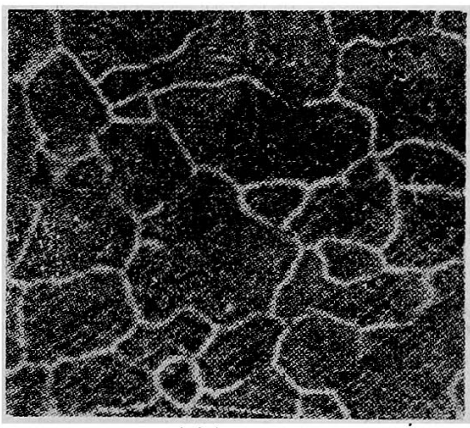

写真 14 .

方法；鉛拡散洼

試料; 鉛快削錩

条件； $925^{\circ} \mathrm{C}$ で才ーステナイト化 $\rightarrow$ 水 䅉入, $1 \% \mathrm{HNO}_{3}$ アルコール溶 液窗睢

（是立，水川，济岡）

9. 陰極電子顕微鏡による方法

試料を㓌極上して加熱しそり表面より霆子在放出させ これ定結像させて鹳察する力法であり，陰極電子顕微鏡 の金相学的研究への応朋は 1933 年 Brüche ${ }^{35)}$ および Johannson ${ }^{36)}$ が高温 Ni の結晶組織を観察したこと から始まりその後鉄鐦に刘しても伐用されるにいたつ た ${ }^{37}$. 佐々木, 岸本, 上田, 黑田, 岡本 ${ }^{33}$ は鏡面仕上げ した炭素鎆， $\mathrm{Ni}-\mathrm{Cr}$ 鋼に奶して $\mathrm{Sr}, \mathrm{Ba}$ 劣，そ扎ら表 


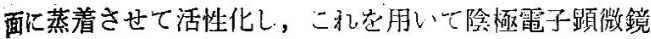
装置により高温組織を锣察している。

\section{III. 各現出方法の適用性に対する検討}

現出方法の操作がいかふうなものですつて試料およ びオーステナイト化の条件が同じ听あ，一般性のあう 現出法であれば判定は全部一致すべきである。しかるに 錼には周知のごとく諸性質のことなつた多くの種類があ るだけにここれらの鋼種全部に適雨出来る現仙法学見い 出すのは困難である. 前項目におういて促来研究されて来 たオーステナイト結继精の現出法を9存類に大别しその 特長简㩆に記述した。

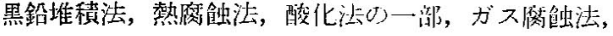

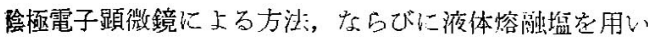
方方法法試料表面の精度在測定し，酸化法の一部，金属 抬散法は試料表面の近辺，淬炭法ならびに熱処理法注試 料の内部を測定している。また高温組織を現出させるの に鋼材内部に他元素を導入きせ元の）鋼材の化学成分上こ となつた状態にするもの上他元索を全く泊入せず直接に 現出する方法とに分颣するこ上も出来方。この上うな分

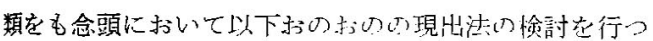
てみる。

1. C 導入による方法

本法は試料中に外部より C 導入し過共析銅にした 状態，るい恽鉛を堆積した状態のものに上つて判定 している. 肌烍鋼に対して，Ｃ遒入は実際にとくし たものであるから支障はないが，そもをも俢炭法はその 楁炭温度ではオーステナイト結晶粒界に炭化物が析出け 才洛炭後冷却漈して Acm 線红当つて初好て網状炭化 物が析出し，オーステナイト結晶精界を現わすのが原則 であるのに炭化物生成元素（クロム，モリブデン，マン ガンなど）を含むと渗炭の梌中すこに網状孷化物を生じ これは成長途次の大きさ現わすもので希望の温度, 時 間のものではない，それに出来た炭化物が球状化しやす く39結晶粒界が切れるので粒度排定が困難になる。 Cのような浸入型固溶原子として原子半径の大きいる のが強制固溶すると応力により結晶成長を促し40)粒度自 体も影響を受ける。また铜材中に $\mathrm{O}_{2}$ 上の親和力の強い 元素たとえば A1 が含有されている上らな場合，渗宸に とむなつて $\mathrm{O}_{2}$ も万り $\mathrm{Al}_{2} \mathrm{O}_{3}$ 定生成する上うになると， この $\mathrm{Al}_{2} \mathrm{O}_{3}$ の存在する部分だけ結晶粒成長が阻止される 現象も考元ら秃 41 加ような個所の粒度它得てもまつたく 無意味なことになつてしまう。写真 15 はこの現象を明 らかにしている。さらに従来の渗炭法は渗炭可能な温度

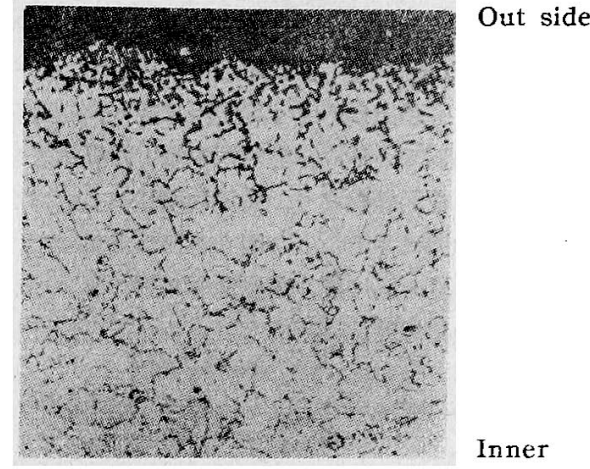

写真 15.

方法；淬炭法 武料; $0.3 \% \mathrm{C}$ 䤼

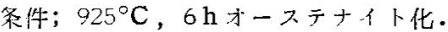
(淩宸武料の表面風の異万位置て現出 丸れ万結晶粒の大きさの比較)

(益子，鬼武)

および保持時問の範囲があり，一般に一定温度，一定時 間 $(925 \mathrm{C} ， 6 \mathrm{~h}$ または $8 \mathrm{~h})$ で渗炭索行つているので単 なる一つの温叐，時間に関しての判定にし加過ぎず実用 的な熱処理粒度からか㚈嚾犳ている場合が多いことる指 摘されているす13)42》。いずれにせ上本法の根本的欠陌は 上記のごとく多くの特殊鋼に実用出来ない点にある。な お西共析部の $\alpha$ 敘の網をみるに一般に細粒銅で法測定 し難い上うである。

黑鉛堆積法について河上，藤曰は俢炭法々ことなり， 粒の成長に際して粒界に堆積している黑鉛も同時に移動 するので粒の過小の部分涀ら札い上述へ，さらに 真空加熱, 瑨入操作, および腐触不要 こ乙操作が簡 単であること，渗炭法に比較して渗炭時間も短かくて 良いことなで黒鉛堆皘法の利点を饬げている。表 1 泩 渗宸法上黑鉛法とによる判定蒙比較するために揭げた ものであり，電解鉄および $0.1 \% \mathrm{C}$ 鋼组関しては两者 閒にほ上んど差のないことを示している。しかしながら この方法も外部汃らの C の䇎入に上万材質変化は必然 的なものであり，その上試料の表面で判定しているので 表面々内部との粒废に差がないかなどの疑問な点を持つ

表 1 。

\begin{tabular}{|c|c|c|c|}
\hline & & 解 鉄 & $0.1 \%$ C 鋼 \\
\hline Mc Ehn 試 験 & & $6 \cdot 0$ & $10^{\circ} 0$ \\
\hline 黒鉛堆稅陚験 & & $6 \cdot 3$ & $10 \cdot 2$ \\
\hline
\end{tabular}

$\left(925^{\circ} \mathrm{C}, 2 \mathrm{~h}\right)$ (河上, 藤) 
つている. 足立,水川, 平岡 ${ }^{34)}$ 忹この熙鉛堆皘法を検討し て極微量の水分があつてる黑鉛の堆䀯は生ぜず，さらに “Sub grain” も現出しやすく判定不可能になる場合为

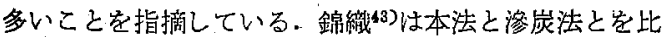
較し表 2 のごとき記録をとり，黑鉛堆積法による方が粒 が小さくなる傾向にあることを明らかにしており不二越 では44) Ni-Cr-Mo 肌焼鋼，高炭素 Cr 鋼，および高速 度鋼に対して黒鉛堆積法は不向きであることを指摘して いる。

表 2.

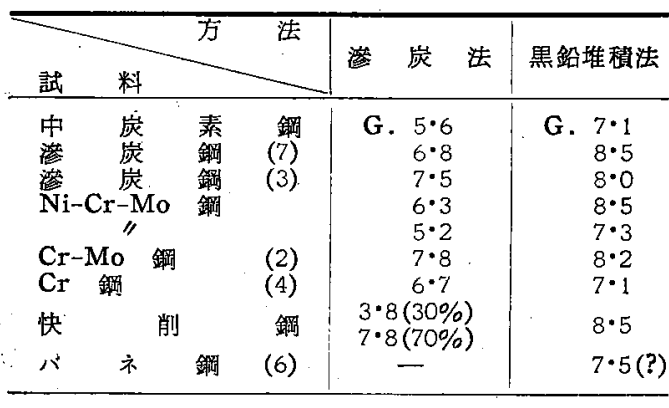

(錦織)

\section{2. 熱妋理法}

本法は他元素の導入によつて材質定变えることもなく しかも試料の内部で粒度装定を行つており，実用的な熱 処理温度，時間にそくしたオーステナイト結晶粒度を合 理的に判定できる場合が多い，以前には加熱後の適当な 冷却速度の選定で苦心を要したが，今日 $\mathrm{S}$ 曲線がよく測 定せられたのでその選定は容易になつた．熱処理法の適 用性を考察するには種々の冷却速度で冷却した組織を連 続的に示してくれる一端焼入法に対する検討で大体代 表できる・一般にトルースタイト（もしくは微細パーラ イト）を析出した状態での粒度判定が容易であるが， Hawks ${ }^{42}$ はCr, Mo が含有されている特殊鋼は普通炭素 鋼のように簡単にはゆかず，ベーナイトが不規律に生じ このためオーステナイト結晶粒の形はみにく〉なる場合 があると報じている．また特にごく細粒の場合，この方 法では結晶粒度をオーステナイト結晶粒度標準図の番号 で言い切る程個々の結晶粒は明確に現われず“Normal” であるか “Abnormal”であるから判定が出来ないこ

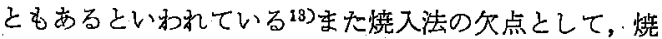
入性の良い鋼に対しては多量の針状組織のために元の才 ーステナイト結晶粒界が認め難くなることなどが挙げら れている30)42)。 また Eckel, Paprocki ${ }^{32)}$ は煤入法によ ると実際には結晶粒界はもつと多くあるべきなのに，部
分的に現出していないことが多く，このような場合整精 であれば閣題はないが混垃の場合には判定を誤るおとれ があることを認めている. 村上》恃熱処理法の適用性に ついてつぎように述べている.すなわち徐冾法行う 場合 $0.45 \sim 0.55 \% \mathrm{C}$ およ゙ $1.1 \% \mathrm{C}$ 以上の宸素鋼は才 ーステナイト化後空中放冷が適当であるが,0・55〜0.7\% Cおよび $1 ・ 1 \% \mathrm{C}$ 鋼に対しては梮中冷却が適当であり， 合金元素を加立た時は冷却速度を適当に加減する必要か ある・一端焼入法は炭素銅，または自硬性定有しない低 合金鋼に対して良い結果吕得られるが $0 \cdot 2 \%$ C以下の低 炭素鋼の場合には冷却水は $10^{\circ} \mathrm{C}$ 以下の冷水または水水 を使用するのが効果的である。交た $0.7 \% \mathrm{C}$ 以上高炭 素鋼の場合には $20 \sim 30^{\circ} \mathrm{C}$ の水它用い試片の一端を水中 に静止して冷却速度を打そくした方が良く，Ni, Mn の ような自硬性元素を含有寸る鋼においてはその組成に応 じて適当に冷却速度を和そくした方が良い。二回焼入法 は操作がやや複雑であり，また焼入不可能な低炭素鋼や 焼入後む炭化物の残るむのまたは $\mathrm{Ac}_{1}$ 变態機構の複雑 なものは粒度現出不可能であるなどの不便があるが，自 硬性特殊鋼にむ適用出来る利点定るつている。

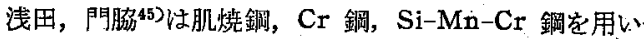
て高温焼㧁法定実施し，その際の腐蝕液に関する検討む 行つて $550^{\circ} \mathrm{C}$ で橴愿した場合は保持時間を， $2 \mathrm{~h}$ 以上と し，焼厥後急泠したものよりも徐泠した方が良く， Vilella 試薬よりも塭化第二鉄塩酸アルコール溶液の力. が効果的であること炭明らかにしている. なた Snyder および Graff(B)は W に富えだ材料，むしくは W-Mo 系高速度鋼の微細なオーステナイト結晶粒を熱処理法で 現出する場合の腐蝕に関して，10\%塩酸+3\%硝酸メチ ールアルコール溶腋で強腐蝕した後，結晶粒界が消失 しないように再研磨するのが効果的であると述べてい る.

3. オーステナイト化に際して真空哣を 用いない現出方法

上記項目には渗炭法, 黑鉛堆積法, 熱処理法も当然含 まれるが，便宜上それらは既述のように独立した項目を 設けたので，こ〉では一般酸化法，液体溶融塩を用いる 方法，ならびに金属拡散法に関して検討したものを挙げ ることにするまず一般酸化法であるが本法は実験操作 も簡単で熱処理から粒度判定までに要する時間も短かく 熱処理粒度を求めるにも好都合であるところから既述の ごとく米国に机いては 1942 年頃から広く採用されてい るが試料表面の酸化現象定利用して結晶粒を現出してい るので鋼中に酸素が入つて材質を変化し，特に困るとと 
沙酸化物による結晶粒成長の抑制なごに上つて誤つた粒 度判定を行う打それがある。陵化㧧によつて現出した結 晶粒が他の現出法によるものと比㬵してしばしば小さい

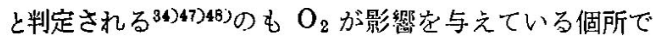
測定しているからである亡，いわゆる酸化物による抑 制説を論ずるものが多い41). 军真 16 (a) (b) は $\mathrm{Ni}-\mathrm{Cr}-$ Mo 鋼を用いてその事実を示したものだ（a）はスケー ル直下，（b）はスケール上り 0.5〜1.0 mm 下の粒を観

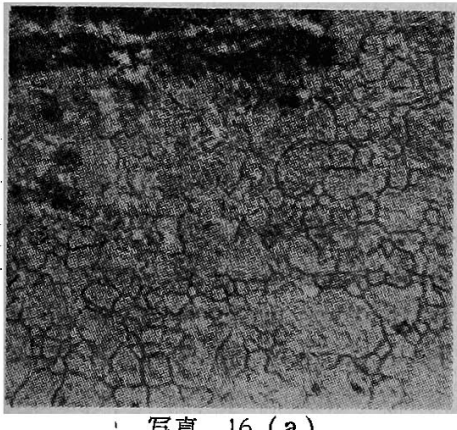

写真 $16(\mathrm{a})$.

方法; 写真 (b) と同じ

試料;

条件;

(スケールの直下)

（益子，鬼武）

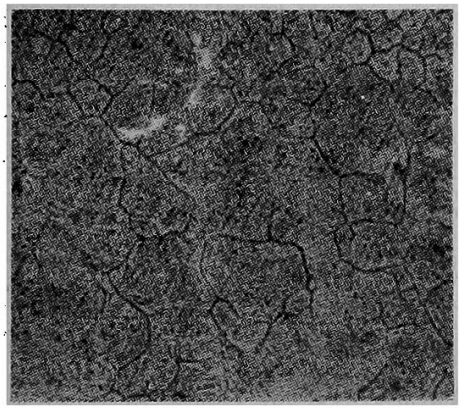

写真 16 (b).

方法; Herasymenko's 酸化法

武料; Ni-Cr-Mo 八ダ焼鋼

条件; $925^{\circ} \mathrm{C}, 6 \mathrm{~h}$ オーステナイト化 (スケールの $0.5 \sim 1.0 \mathrm{~mm}$ 下)

(益子, 鬼武)
察したものであり，前者の結晶精が小さく諗められる。 また表 3 は酸化法, 焼入法, 2 回焼入法による粒度 の比較を行つたものであり，酸化法に上る粒は細かく なつている. 河合48) は鋼を空気中で高温加熱すると鋼 の $\mathrm{Cu}$ 名表面に富化さ扎て，結晶粒界に $\mathrm{Cu}$ 合金層を 生じ，この層によつて次段階の結晶䊀成長に对して影響 を与えることを指摘している，道子，鬼武 ${ }^{41}$ は酸化によ り結晶粒成長抑制層の出来る事实にもかかわらず酸化法 による粒度が種々の鋼種と加熱条件下で他の方法による 粒度と良く一致する場合が多いことに対してつぎのよう な説明を行うている。試料を大気中で加熱すると，試 料面は酸化されて酸化物層が形成され，酸化物層の直下 から試料内部へ向つて酸素浱度の公配が生じる.さらに 時間が経過するとスケールは潮次厚くなつてゆき，酸 素搌度の勾配も内部に向つて移動して行くのであるが， 粒界は拡散が容易であるから，粒界の酸化前線は内部に 向つて先行している.また拡散した酸素の量がある值以 上になるとそれは酸化物層として析出する. 試料表面に みられるスケールはこの典型的なものであるが，内部に おいては析出初期の酸化物がある訳で，これはまた時間 上ともに成長する.しかしこの内部における酸化物の大 きさはある值をはさんで二つに分けられる.すなわちそ の值以上に大きくなると粒界の移動を妨げることが出来 る.すなわち図 1 の第 1 層は酸化物の大きさがある臨 界值以上であり，こつでは結晶稙の成長が阻止され， 第2. 層では酸化物は結晶粒の成長を妨け゚る程大きくはな いがすでに析出しており，しかもとれは粒界に沿うて 内部に優先的に侵入している。ゆえに粒度の測定に当り もし第 1 劂付近を観測すれば，結晶粒は細かく測定され

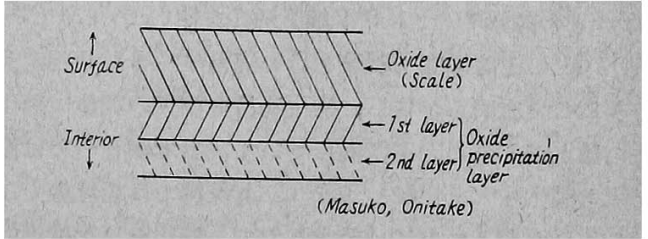

図 1.

表 3 .

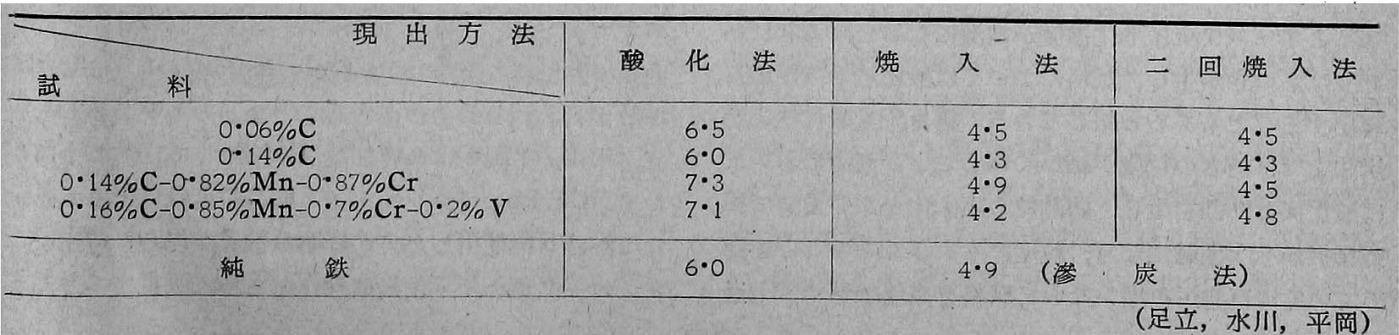


表 4.

\begin{tabular}{|c|c|c|c|c|c|c|c|c|}
\hline \multirow{2}{*}{ 材 } & \multirow{2}{*}{$\begin{array}{l}\text { チャーシ } \\
\text { 番 带 }\end{array}$} & \multicolumn{3}{|c|}{ オーステナイト結晶料度 } & \multicolumn{4}{|c|}{ 差 } \\
\hline & & Go & $\mathrm{Gc}$ & $\mathrm{Gh}$ & Go-Gc & Go-Gh & & \\
\hline 中 炭 荤 & $\begin{array}{c}1 \\
2 \\
3 \\
4 \\
5 \\
6 \\
7 \\
8 \\
9 \\
10 \\
11 \\
12 \\
13 \\
14 \\
15 \\
16 \\
17\end{array}$ & $\begin{array}{l}7.5 \\
7 \cdot 5 \\
7 \cdot 0 \\
2 \cdot 5 \\
4 \cdot 8 \\
7 \cdot 0 \\
6 \cdot 5 \\
7 \cdot 5 \\
6 \cdot 2 \\
8 \cdot 0 \\
7 \cdot 5 \\
7 \cdot 8 \\
7 \cdot 1 \\
8 \cdot 0 \\
7 \cdot 6 \\
7 \cdot 7 \\
5 \cdot 8\end{array}$ & $\begin{array}{l}6 \cdot 8 \\
7 \cdot 2 \\
6 \cdot 8 \\
2 \cdot 5 \\
4 \cdot 8 \\
6 \cdot 8 \\
6 \cdot 5 \\
6 \cdot 8 \\
6 \cdot 1 \\
7 \cdot 5 \\
7 \cdot 0 \\
7 \cdot 9 \\
7 \cdot 1 \\
7 \cdot 4 \\
7 \cdot 8 \\
7 \cdot 6 \\
5 \cdot 8 .\end{array}$ & & $\begin{array}{c}+0.7 \\
+0.3 \\
+0.2 \\
0 \\
0 \\
+0.2 \\
0 \\
+0.7 \\
+0.1 \\
+0.5 \\
+0.5 \\
-0.1 \\
0 \\
+0.6 \\
-0.2 \\
+0.1 \\
0\end{array}$ & & 混 & 粒 \\
\hline $\begin{array}{c}\text { 中 炭 素 } \\
\text { (S F 55) }\end{array}$ & $\begin{array}{l}18 \\
19\end{array}$ & $\begin{array}{l}1 \cdot 7 \\
1 \cdot 9\end{array}$ & $\begin{array}{l}1 \cdot 7 \\
2 \cdot 0\end{array}$ & & $\begin{array}{c}0 \\
-0.1\end{array}$ & & & \\
\hline 中 $\mathrm{C}-\mathrm{Cr}-\mathrm{Mo}_{0}$ & 20 & $8 \cdot 0$ & $7 \cdot 8$ & $8 \cdot 0$ & $+0 \cdot 2$ & 0 & & \\
\hline パ辛鎆 & 21 & $8 \cdot 0$ & $8 \cdot 0$ & $8 \cdot 0$ & 0 & 0 & & \\
\hline 低 C-Si-Cr-Mo 鉶 & $\begin{array}{l}22 \\
23\end{array}$ & $\begin{array}{l}5 \cdot 0 \\
6 \cdot 2\end{array}$ & $\begin{array}{l}4 \cdot 4 \\
5 \cdot 3\end{array}$ & & $\begin{array}{l}+0.6 \\
+0.9\end{array}$ & & & \\
\hline 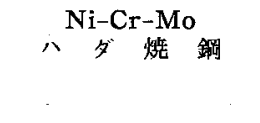 & $\begin{array}{l}24 \\
25 \\
26 \\
27\end{array}$ & $\begin{array}{l}4 \cdot 0 \\
7 \cdot 0 \\
7 \cdot 0 \\
7 \cdot 0\end{array}$ & $\begin{array}{l}2 \cdot 5 \\
6 \cdot 8 \\
6 \cdot 8 \\
7 \cdot 0\end{array}$ & & $\begin{array}{l}+1 \cdot 5 \\
+0 \cdot 2 \\
+0 \cdot 2 \\
0\end{array}$ & & 混 & 粒 \\
\hline
\end{tabular}

Go; 酸化法, Gc; 滲炭法

第 2 層近辺を觀測すれば真の值が得られる訳である。 表 4 は渗炭法の結果と良く一致することを示してている. 一般酸化法について, Tobin, Kenyon は Miller, Day との論議28)でキルド鋼 2 種類を用いて $870^{\circ} \mathrm{C} \sim$ $1095^{\circ} \mathrm{C}$ の温度範囲で試験索行い満足すべき粒度判定が できることを明らかにし，酸化物層の消失の調整に酸化 法の難点があることを指摘している. 日本銅管50’では俢 炭法と酸化法とを比較し $925^{\circ} \mathrm{C} 6 \mathrm{~h}$ 保持では粗精鋼でな いかぎり両者とも良く一致するので，酸化法忹実用可能 であるが，粗粒鎆の場合には酸化法の方が細かに表わさ れ，しかむその差は一定でなく，さらに $1000^{\circ} \mathrm{C}, 1100$ ${ }^{\circ} \mathrm{C}$ とオーステナイト化温度が高温炕なる両者間にか なりばらつきが生じ，試料比よつては酸化法の方が粗く 現出することもあると報じている.富永 ${ }^{47}$ も酸化法と渗 炭法とで法前者の粒度が細かくなること，高温汇拉いて は酸化面は凹凸を生じ，結晶粘の粗大化とあいまつて視 野撰択がや〉困難になり，粒度差む大きくなることを認 めている. 真空炉を用いないで試料意高温加熱しても過
度の酸化が起らぬようにとのことから液体溶融塭中でオ ーステナイト化する方法む検討されている.これは従来, 表面組織の研究用また住銅拡散法の予備処理として用い られたものであるが，それ自体オーステナイト結晶粒度 測定法としてあ用いられるはずである。ただ現出機棈か ら考えて真の粒度より細粒として現われる傾向があると． 思和る。金属搪散法は試料のや〉内部を観察している 有利な点を持って抢り多くの鋼材に対して適用性のある ことも示されているが3238452)，オーステナイト化に既述 の“Sandwich”を使用した場合,試片之試片との間には さんだ金属と陚料表面との反応の有無，硍砂浴中でオ一 ステナイト化した場合は硼砂中への $\mathrm{O}_{2}$ の溶解, さらに 金属拡散处理の際 “Sub-grain boundary”比金属 拡散が行われるおそれがあることなどの不安がある.足 立, 水川，平岡34 は金属拡散法を検討して，拡散金属と して, $\mathrm{Cu}, \mathrm{Pb}$ ずれを用いても結晶粒度はほとえど差が ないが, $\mathrm{Pb}$ を使用した方が鮮明な粒界が得られやすいと と，オーステナイト化処理操作をさらに改良すべきであ 


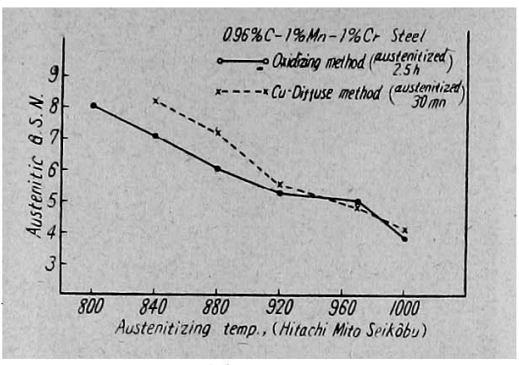

図2.

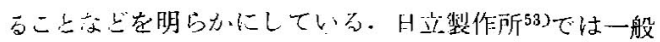
酸化法上 $\mathrm{Cu}$ 拡散佧と老セメンタイトの球状化した軸受

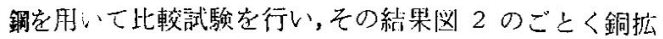
散法で注酸化法上りも細亦く特に $880^{\circ} \mathrm{C}$ 以下では球 状化セメ:タイトの固溶に充分でないためその差がいも じちしいこ，球状化セメンタイトの固溶した温度に沶 いては両者とも比較的同一の值を示すことを明らかにし

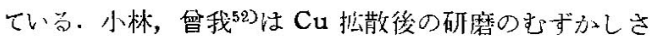
指摘しこいる。

4. オーステナイト化に際して真空炣すしく は不活性ガスを用いる方法

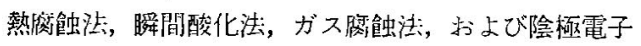
顕微鏡に上る方法がこの種類に鹤する。この四者とも試

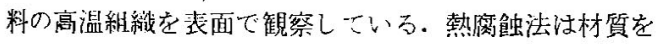
変えるこよなくオーステナイト結晶粒を垷出するので多 くの鋼材に封して適用される可能性が強く, 高温顕微鏡 に上万研究に対してもこの熱腐蝕が多く用いらられてい る。しかしながらオーステナイト結晶粒度る判定するに は所定温度，特間保持した時の結晶粒界だけが必要であ るにもふかわらず熱應玲の原理からも明らかなように加

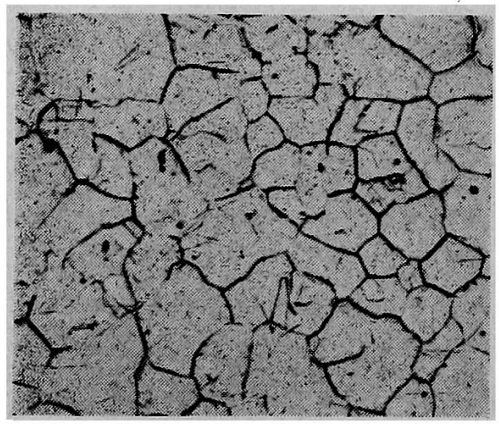

方法; 熱窗蝕法

$$
\text { 写真 } 17 .
$$

試験; 25-20 ステンレス鎆

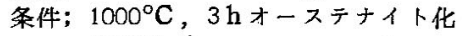
瓷蝕せず

(今井, 広谷)
熱速度孔よび领却速度が禾そい場合は写真 17 で示され るように成長以前の結晶粕界が残存したり，試料によつ ては $\alpha$ 鉄の絬晶䊀界が現出されたりして判定を困惑させ る場合があり，伶却速度を早めると良い結果が得られる こはいえ27烸入北空真空あるいは不活性ガス中で行わな ければならないこころから装置はや〉複䧱化する・オー

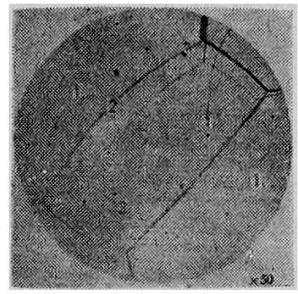

(a)

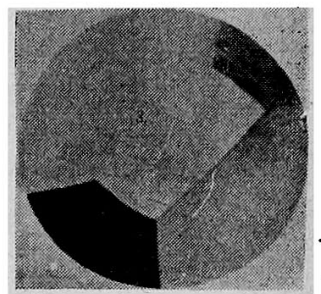

(b)
写真 18.

方法：（a）熱窗蝕法

(b) 陰極電子顕微鏡法

試料：盲 $\mathrm{Si}$ 鈯

条件； $1200^{\circ} \mathrm{C}$ でオーステナイト化

((a)，（b）は同地域)

（遠藤，大竹）

ステナイト化後の泠却涑度による粒度の差は勿論な い29．前还のような不必要な粒界が生じていても試料の 同一視野を除極電子显溦鏡によつて観察寸る上熱腐蝕法 によつて現出された複維な線の中に一致した結晶粒界が 存在しているこ上当明らかにされている14)a8). 字真 18 (a)（b）は上述のこ上を示したものであるがが(a)が熱 腐蝕によつた場合 (b)が㓌極電子題微鏡を使用した場合 で記号3の線が求るるべき結晶粒界である．熱腐蝕法の もら一の0攵よして真空加熱によつて結晶粒界に存在 する“Amorphous Cement”蒸発させるには（ある いは表面張力によつて頪界を現出させるに泣)高温, 長時 間保持の方方効果的であり,低温度, 短時問では粒度判定 に足りるだけ刻まれないことがある。その点高温着色法， 瞬間酸化簡便法和よびガス鹰蝕法は求めるべきその時の オーステナイト結晶粒界を鮮明に現出するので熱腐蝕法 の難点は取り除かれているが別な短所が指摘される。高 温着色法およびガス触蝕法は鋼種によつて酸化度，むし くは腐蝕度がここなり，結晶粒度の判定に適するように 現出ずるには空気量,ガス量を調整しなけれいばならない。 高温顕微鏡での研究のように隭蝕する個所を観察しなが ら空気,ガス量堂調整するならばともかく，應蝕個所を観 測することなしに恉色の好条件を知るには経騟家必要と する・かようなとこるから考えると瞬間酸化簡便法は自 然酸化であり，その後の砞砂浴に浸す時間も鋼種が変つ ても大差なく，硼砂浴に浸すことによつて，たとえ液体溶 
融熄を使用して現出する方法の場合のように脱炭現象が そもなつても唧砂浴に浸す前に存在したオーステナイト 結晶粒界は固定されてしまつているので脱炭に無関係で あるゆえ広範囲に適用されると考えられるが真空炉もし くは不活性ガスを用いる方法としての共通な疑問点を有 している.それは前述のょうにこの種の現出法は試料表 面の粒度を判定してていが果して内部の粒度が表面と同 一であるふ否かの点である. 熱腐蝳法によつて現出した オーステナイト結晶粒は他の方法によるるのと比較して 小さく判定されることが多いといわれている28)51154555). この原因として一般酸化法で述べたことと同じようなこ 之も考えられている. 一般酸化法の項でオーステナイト 化処理の際酸化物生成によつて結晶粒度の判定を誤らせ る可能性が多くあることを述べたが真空忓および不活性 ガスを使用する大きな目的はオーステナイト化の㭙の酸 化を防ぐことにあるので，その真空度ならびに不活性ガ スの清浄度, 特に酸素の存在量に注意を払わなければ真 空炉なよ゙を用いない場合之同じような結果を招くような ことになる. Miller, Day ${ }^{28)}$ は 0.6\% C, 0.1\% Al を 含有した鋼材を使用して熱鹰蝕法と熱处理法とを併用し て表面で測定した粒度とや〉内部で測定したものでは 值がことなるこ上を認めた，写真 19 はこの鋼を水素中 で熱腐蝕し; 真空中でや〉烧戻してがら表面を5 100 の角度で切断して表面の結晶粒成長が阻止されているこ とを示したものであり，細粒層の厚さ仕大体 $0 \cdot 001$ inch ある・このような現象の起つた原因として，水素の清浄 度定とりあげ，水素中に残存している酸素が試料表面の

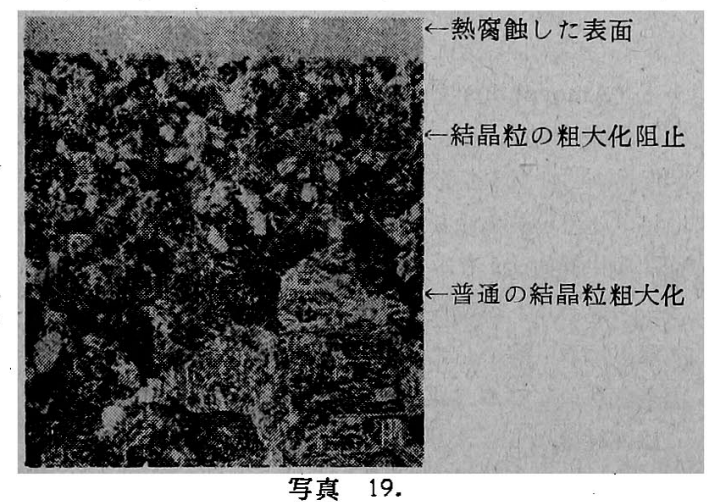

方法：熱窝蝕法（表面）执よび烧戻、 ルテンサイト窗蝕法

試料: $0.6 \% \mathrm{C}, 0.1 \% \mathrm{Al}$ 鍓

条件: $1205^{\circ} \mathrm{C}, 30 \mathrm{mn}$ オーステナイ 下化

（熱窗蝕中, 表面および表面付近のオ一 ステナイト結晶䊀に和よばす水素中の 酸素の影響）

((Miller, Day)

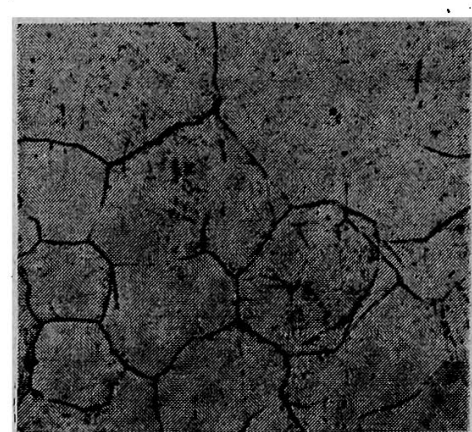

(a)

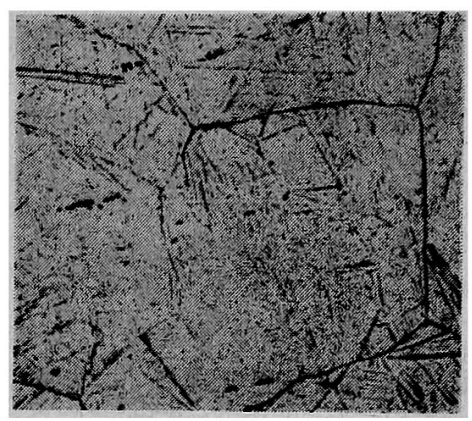

(b)

写真 20 .

$1205^{\circ} \mathrm{C}, 30 \mathrm{mn}$ の熟窝蝕法により生 ずる $0.6 \% \mathrm{C}, 0.1 \% \mathrm{Al}$ 鍓のオース テナイト結晶粒に扎よはすす酸素の影響

a) 磁製管

b）燒結純アルミナ管

(Miller, Day)

$\mathrm{Al}$ と結合して $\mathrm{Al}_{2} \mathrm{O}_{3}$ を生成し，これが結晶精成長索阻 止していることを挙げている.さらにその㸀付け実験と して熱処理に用いるチューブの違いによつても外部から の酸素の侵入度がことなり，これによつて結晶粒度が左 右されることを明らかにしている，写真 20 (a) (b) は 磁性管と. $\mathrm{Al}_{2} \mathrm{O}_{3}$ 管の比較であり, 酸素の侵入しやすい 磁性管を用いた場合絬晶粒が微細化されている. なた水 素の清浄度を変えてオーステナイト化温度の上䒜にとる なう結晶粒の変化を求めている. 写真 21 (a) (b) お よび四3汢その例であるが，清浄度の良い場合は熱処 理法と 熱腐蝕法とで 差はないが，清浄度が悪いと熱腐 蝕法によるものつ方が細かくなつている，微量 Zr が含 有されている場合す A1 の場合と同じような現象它認め ている：結晶構造上からみて上述のような結晶粒成長阻 止因子の有無の考えを入れなくても，金属それ自体の状 態が自由表面と内部とで果して同一であるか一層の検 討を要するが55)不活性ガス中で熱腐触した結果の中表 


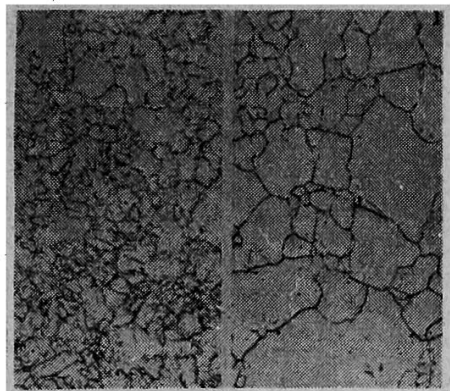

(a)

写真 21

$0.6 \% \mathrm{C}, 0.1 \% \mathrm{~A} 1$ 銅 $1205^{\circ} \mathrm{C}, 30 \mathrm{mn}$ 熱蝕简して現出するオーステナイト結 晶粒に扣よばす酸素の影㽧

a) スケールのついた研䄷しない側の 試料 b) スケールの含まない試料 (Miller, Day)

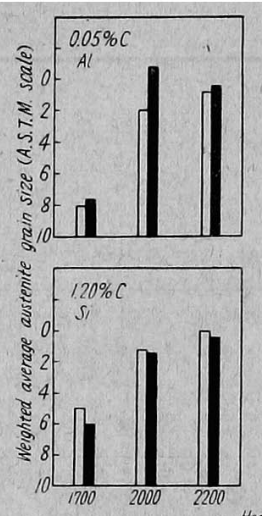

White; heat etch, black; temperad 20002200 martensite

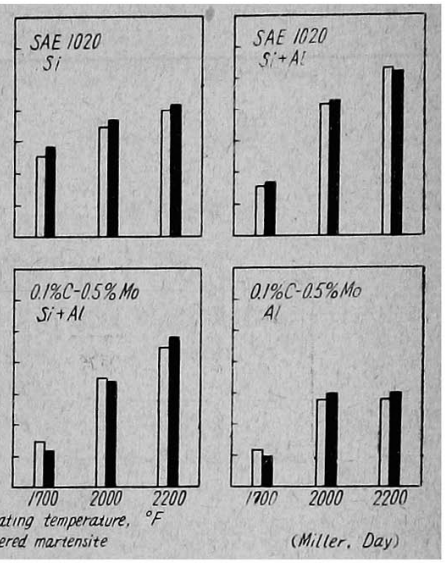

図 4.

5 および図 4 のごとく他の現出方法々一致することむ 認められているので，この不安もいくらか取り除かれて はいる.このようなことょりこの真空炉ならびに不活性 ガス起使用する現出法はその䨝囲気の清浄度 に細心の注意を払えぼ一層広範囲に適用され るようになることと思われる。ただしこの場 合, 清浄装置む必要であるため試験装置の複 雑化することは免がれないようである。

\section{5. 破面検査法}

本法は試験方法の簡単なこ上，および材質 を变化するここなく結晶粒度を求めることが 出来るところから古くから採用されておりオ ーステナイト化後急冷によつて多量のマルテ ンサイトが生じるような鋼材に醚用性がある といわれている(9)(30)42). Shepherd ${ }^{812}$ 法粮度 判定の際，判定者を多くするこ上，多くの試 料について試験を行のうなどの細心の註意を 払いさえすれぱ正確に粒度を求めることが出

表 5.

\begin{tabular}{|c|c|c|c|c|c|c|c|c|c|c|c|}
\hline \multicolumn{12}{|c|}{ 種々の現出法による $0.94 \%$ C 鋼の結晶粒度の比較 } \\
\hline \multicolumn{4}{|c|}{ 処 } & \multicolumn{3}{|c|}{ 理 } & \multicolumn{4}{|c|}{ 結 晶 粒 度 (A.S.T.M. No.) } & \\
\hline 保 & 持 & & 時 & 間 & $11 \mathrm{r}$ & $\mathrm{mn}$ & $1450^{\circ} \mathrm{F}$ & $1550^{\circ} \mathrm{F}$ & $1650^{\circ} \mathrm{F}$ & $1750^{\circ} \mathrm{F}$ & $1850^{\circ} \mathrm{F}$ \\
\hline $\begin{array}{l}\text { 熱 } \\
\text { 焼 }\end{array}$ & 戻 & $\begin{array}{l}\text { 商 } \\
+\end{array}$ & 粒 & 蝕 & 腐 & $\begin{array}{l}\text { 法 } \\
\text { 蝕 }\end{array}$ & $\begin{array}{l}8 \sim 7 \\
8 \sim 7 \\
8 \sim 7\end{array}$ & $\begin{array}{l}7 \\
7 \\
7\end{array}$ & ${ }_{6}^{6} \sim^{5}$ & $\begin{array}{c}4 \\
5 \\
5 \sim 4\end{array}$ & ${ }_{4}^{3} \sim_{3}^{3}$ \\
\hline 保 & 持 & 更 & 時 & 間 & $60 n$ & $\mathrm{mn}$ & & 1 & & & \\
\hline $\begin{array}{l}\text { 熱 } \\
\text { 炾 }\end{array}$ & 戻 & $\begin{array}{l}\text { 腐 } \\
+\end{array}$ & 粒 & 蝕 & 准 & $\begin{array}{l}\text { 法 } \\
\text { 蝕 }\end{array}$ & $\begin{array}{l}8 \sim 7 \\
8 \sim 7\end{array}$ & $\begin{array}{l}7 \sim 6 \\
7 \sim 6\end{array}$ & $\stackrel{5}{6 \sim 5}$ & $\frac{4 \sim_{4}^{3}}{3}$ & $\begin{array}{l}3 \\
3\end{array}$ \\
\hline
\end{tabular}




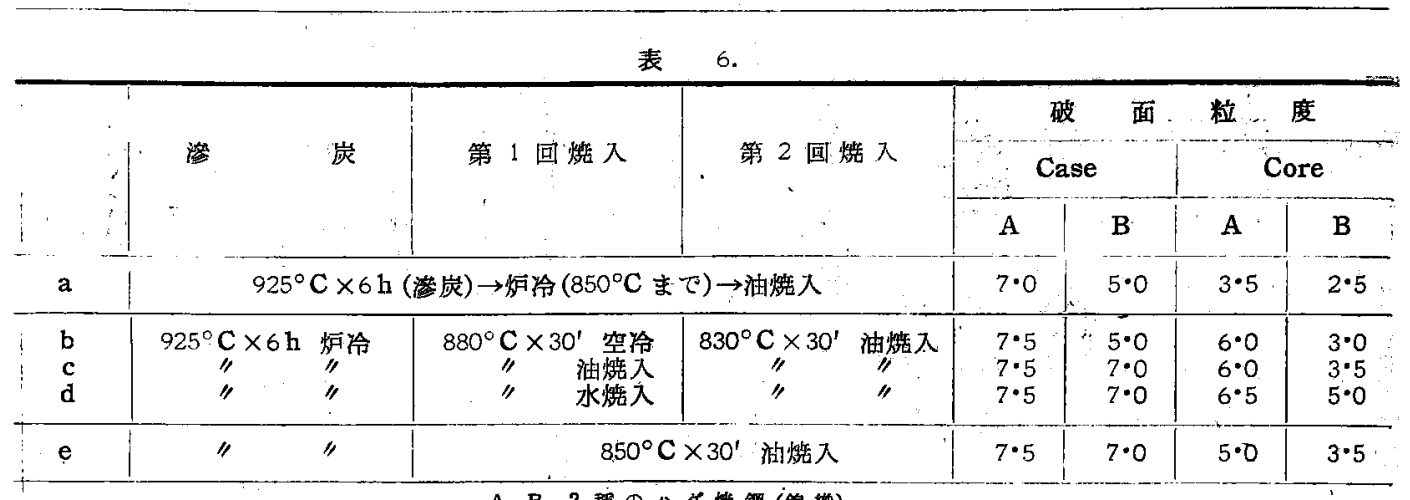

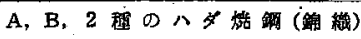

来ると述心ている.

Velella, Baing》 は Shepherd, および Jernkontoret の破面粒度番号と A.S.T.M. のオーステナイト結 晶粒度番号と直線的関係のあることを明ら汃にし, 浅田 門脇 ${ }^{45)}$ は(低合金鋼を用いて高温焼戻法を行つてそれらの オーステナイト結晶粒度と, その鋼材の破面粒度を求め て, Jernkontoret 法による破面粒度番号とオーステナ イト結晶粒度とやはり直線的な関係のあることを確認し ている. Hawks ${ }^{42)}$ 性破断法の適用性を検封して焼入性 の悪い鋼材には不適当であること，混粒に対して正確な 判定を行うことが出来ない場合が多いこと胡などを報じ ている.また錦織す7はオーステナイト結晶粒度のことな ○た 2 種類の肌跴鋼を用いて表 6 のように渗炭後種々 の熱処理を施し，破咪して破面の熱処理方法との関係を 調心，渗炭後炬内で $850^{\circ} \mathrm{C}$ まで伶却して直接油焼入す， ると破面粒度が最も粗いとと，浸炭後炉冷し， $850^{\circ} \mathrm{C}$ に再加熱して一回焼入すると破面粒度はやや細かくなる など; 滲炭後の熱処理により破面粒度はことなることを 明らかにてている。

\section{IV. 結}

言

オーステナイト結晶粒の現出法に関しての研究は古く から行われており，それぞれ特長を持うた方法が多く発 表されている今日，個々の鋼材の結晶粒度を判定する場 合, 、かなる現出法㟟ら゙べきであるか，また今後一層 一般的な現出法を見い出すためにはどのような点に考虑 する必要があるかの目安をつけるために従来行われてき た各種の現出法の種類を分類し，さらにそれぞれの現出 法の特長を検討した。

一般に熱処理粒度を求奶たい場合が多い点からみて, 結晶粒度の現出法の最も大切なものは材質を变えること なく，鋼材全体の粒度它代表できるようにすることにあ るが，性質のことなつた多くの鋼種に簡単に適用できる
現出法の発見は難かしい，かような状態において結晶粒 度を判定するには判定すべき鋼の材質および熱処理条件 と照らし合わせて目的にそう現出法を採用しなければな らない．各項目で論じて来たように幸いにして各現出洼 は鋼材に対する適用範囲かととなつて接り，そのいずれ かを採用すこるとによつて大抵の実用鋼材の真の結晶粘 度を求めるここが出来るように思和れる。な打本資料 中，従来一般㲸用い!られている現出法の細加い技術上の 問題は割愛した。（昭和 $33-7$ 月寄稿）

$$
\text { 交 “.”献 }
$$

1) H. W. McQuaid, E. W. Ehn: T.A.I.M.E. 67 (1922) 341

2) Grain Size Symposium: T.A.S.M. 22 (1934) 861

3）日本鉄䤡協会：“錒の処理”（1957年丸善発行） p. 214

4) 米国金属学会: “Metals Hand book” (1948) p. 400

5) 日本鋼管 K. K.: 第 6 回 JIS 結晶粒度試験方法 専門委員会 (1955)

6）河上，藤：日本金属学会誌 16 (1952) 8; 447 ：

7 ）村上: 日本金属学会誌 6 (1942) 3, 75

8) Grossman: T.A.S.S.T. 21 (1933), 1079

9) J. R. Vilella, E. C. Bain: Metal Prog. 30 (1936) 9,39

10) E. S. Davenport, E. C. Bain: T.A.S.M. 22 (1934) 879

11) P. Herasymenko: Metal Prog. 30 (1936), 9, 69

12) Steel Standardization Group: Metal Prog. 41 (1942) 3, 332

13) H. Tobin, R. L. Kenyon: T.A.S.M. 26 (1938) 133

14) 遠藤, 大竹：日本金属学会誌 19 (1955) 2, 51

15）今井，広谷：鉄と鋁， $44(1958) 4,480$

16) F. Osmond, G. Cartaud: Ann.des Mines (9) (1900) 18, 113

17) A. Baykoff: Rev. de Met. (1909) 6, 829 : : 
18) P. Oberhoffer: Z. für Electrochem. 15 (1909) 634

19）河上，染野：鉄と鍮，44（1958）1，33

20) 江口：末発表

21) E. H. Saniter: J.I.S.I. 52 (1897), 115, 53 (1898) 206

22) F. Osmond: Ann. des Mines. 9 (1900) 17, 110

23) F. Osmond: Ann. des Mines (8) (1888) 14,5

24) W. Rosenhain, D. Ewen: J. Inst. Met. 8 (1912) 149

25) G.W.C Kaye, D. Ewen: Proc. Roy. Soc. A (1913) 89,58

26) H. O' Neill: J.I.S.I. 135 (1937) 187

27) M. J. Day, J. B. Austin: T.A.S.M. 28 (1940) 354

28) O. O. Miller, M.J. Day: T.A.S.M. 30 (1942) 541

29) M. J. Olney: Metal Treat. 19 (1952) 347

30) A. Færden: Metallurgia, 54 (1955) 3

31) B. F. Shepherd: T.A.S.M. 22 (1934) 979

32) E. J. Eckel, S. J. Paprocki: T.A.S.M. 41 (1949) 1204

33）的場，笠松：学振 19 委 4075 (1956)

34）足立, 水川, 平岡：鉄之鋼 43 (1957) 11, 1129

35) E. Brücke, H. Johannson: Z. Tech. Phy.14 (1933) 485

36) E. Brücke, W. Knecht: Z. Tech. Phy. 15
(1934) 461, \& 16 (1935) 95

37) W. E. Burgers: J.J.A.P. Amstel, Physica, 4 (1937) 15

38）佐々木，岸本，上田，埋田，岡本：日本金属学会 誌 16 (1952) 3, 165

39) 村上, 今井, 中島：日本金厤学会誌 7 (1943) 8, 336

40）今井，神山：鉄と鎙 42 (1956) 3，179

41）益子，鬼武：住友金属 8 (1956) 236

42) M. F. Hawkes: Metal Tech. 14-1 (1947) T.P. No. 2170

43) 錦轼: 学振 19 委 3573 (1954)

44) 不二越 K.K.: 学振 19 委 3736 (1955)

45）浅田，問䏦：铁之鎆 42 (1956) 6, 476

46) R. W. Snyder, H. F. Graff: Metal Prog. 33 (1938) 4, 377

47) 富永: 学振 19 委 3430 (1954)

48) 河合: 学振 19 委 3999 (1955) \& 4016 (1955)

49) 富永: 学振 19 委 3735 (1955)

50) 日本鋼管 K.K.: 学振 19 委 3570 (1954)

51) 小出：学振 19 委 4386 (1956)

52) 小林, 曾我: 学振 19 委 4073 (1956)

53）日立製作 K.K.(水㝎)：学振 19 委 4076 (1956)

54) 沢村, 盛, 滕田, 一瀬：学振 19 委 4383 (1956)

55）長谷部：住友金属 9 (1957) 4, 13

56) N. F. Ward, J. E. Dorn, Met. and Alloys: 10 (1939) 115

57）錦織: 学振 19 委 4071 (1956) 